\title{
Forest - Related Culture and Contribution to Sustainable Development in the Northern Mountain Region in Vietnam
}

\author{
Thi Tan Huong Ngo $^{1}$, Thi Phuong Mai Nguyen ${ }^{2, *}$, Thi Huong Duong $^{1}$, Thi Hue Ly ${ }^{3}$ \\ ${ }^{1}$ Faculty of Basic Sciences, TNU - University of Economics and Business Administration (TUEBA), Thai \\ Nguyen, Vietnam; tanhuong@tueba.edu.vn; dthuong@tueba.edu.vn \\ 2 Faculty of Environment and Natural Resources, TNU - University of Sciences (TNUS), Thai Nguyen, \\ Vietnam; maintp@tnus.edu.vn \\ ${ }^{3}$ Faculty of State - Law and Theoretical Foundations, National Academy of Public Administration, Hanoi, \\ Vietnam; lythyhue@gmail.com \\ * Correspondence author: maintp@tnus.edu.vn ; +84-965156068
}

\begin{abstract}
The culture of communities living near/in forests indelibly interacts with forest ecosystems, both shaping and adapting to the natural environment. Forest-related cultural dimensions also provide benefits for local economies and social welfare. This study analyses the relationship between local culture and forests of the Tay and the Dao minorities and their contribution to sustainable development in Vo Nhai, a mountainous district in northern Vietnam. The study uses methods of a literature review, participant observation and qualitative interviews with local people. The strong embedded culture with forests that developed over many generations of Tay and Dao people was expressed through their knowledge systems of understanding nature, skills for environmental adaption, health protection and spiritual and recreational activities. The potentials of forest - related culture as a feature of local sustainable development were analysed through contributions in natural resource conservation, economic development and social cohesion. To integrate forest - related culture in sustainable development, some issues need to be better focused on the locality.
\end{abstract}

Keywords: cultural ecosystem services; forest-related culture; northern Vietnam; local knowledge; sustainable development

\section{Introduction}

The complex interaction of human culture and ecosystems have been concerned with both social and natural resource studies in several recent decades (e.g. Bennett, 1944; Goucher et al., 1998). Ecosystems deliver goods and services of enormous value to the human society (Costanza et al., 1997; Daily, 1997; MA, 2003). Humans are one of the living components of the ecosystem, they interact with other components to produce impacts and also obtain benefits for society, called "ecosystem services". Ecosystem services are categorised into supporting, provisioning, regulating, and cultural services (MA, 2003). Cultural ecosystem services are defined in the MA framework (2003) as a term of the nonmaterial benefits people obtain from ecosystems through spiritual enrichment, cognitive development, reflection, recreation, and aesthetic experiences. Cultural ecosystem services must demonstrate a significant relationship between ecosystem structures and functions specified in the biophysical domain and the satisfaction of human needs and wants specified in the medical/psychological/social domain (Daniel et al., 2012). The cultural services, in any further consideration, are often characterized as being "intangible," "subjective," and difficult to quantify in biophysical or monetary terms (MA, 2005). Some categories could not be assessed from the available information (Schaich et al., 2010). Moreover, the cultural service definitions are not distinct (Milcu et al., 2013; Norton et al., 2012; Satz et al., 2013) or overlap with other service categories (Chan et al., 2012; Norton et al., 2012). 
Culture is defined as the patterned behaviours that a social group develops to understand, use, and survive its environment (Goucher et al., 1998). Not all cultural values can be fit into the ecosystem framework, and they vary according to people's perceptions of the ecosystem (Daniel et al., 2012; FAO, 2009; Norton et al., 2012). Because of local features of culture, many cultural service studies were done at a local scale (Bieling \& Plieninger, 2013; Brancalion et al., 2014; Burkhard et al., 2014; Plieninger et al., 2013; Szücs et al., 2015). The preservation and survival of local cultures is critically dependent with forests and nature, and vice versa (FAO, 2009). This condition defines the inseparable relationship of culture and ecosystems. Thus, understanding culture relationships to the forest and the natural environment considerably serves as a key component of engaging on sustainable ecosystem management (FAO, 2009; Retallack \& Schott, 2014), which directly contributes to sustainable development.

Sustainable development has been defined by the United Nations as "development that meets the needs of the present without compromising the ability of future generations to meet their own needs". Sustainable development requires the balance between natural resources utilitisation for social economic development and ecosystem service conservation that contribute to human wellbeing and livelihoods. Therefore, integrating ecosystem services into development planning is a necessary process for achieving sustainable development goals (GIZ, 2018). Many cultural practices related to ecosystems have an important role in social capital and enhancing social welfare (MA, 2005a). Socio-economic development based on local forest ecosystem services can produce winwin results in the relationship between economic development and environmental protection. It serves an especially important role when people have suffered the negative effects of global climate change and forest degradation.

Since the 1990s, researchers have demonstrated the variety of cultures in the northern Vietnam mountainous areas and the dependence of local communities on the environment (i.e. CRES, 2001; Le, 1998, 1999). Therefore, the locality and local human ecology, especially culture of indigenous people, should be respected and promoted in programs or projects of rural mountainous area development initiatives in Vietnam (Le, 1999; Phan \& Le, 2017). Additionally, the change of ecosystems and socio-economic conditions lead to the change of local culture, and vice versa. Keeping all these considerations in mind, we chose a case study in Vo Nhai district, Thai Nguyen province, a centre of Viet Bac region in northern Vietnam.

Vo Nhai is a mountainous district with natural limestone landscapes with significant forest cover, and which is inhabited by numerous ethnic groups (the Tay and the Dao) whose many cultural characteristics are still preserved. However, the natural forests have degraded in part as a result of activities among local communities living in and around forests, including illegal hunting, logging, and shifting cultivation practices that have been deemed illegal by the government (Do, 2012; T. T. Nguyen, 2014; TSPHMB, 2012a). Thus, this paper aims to analyse the forest - culture relationship and potentials of forest cultural services in sustainable development in Vo Nhai following the ecosystem services framework towards identifying and establishing win-win relationships in natural resource conservation and development at the local scale. Results provide support for policy makers considering trade-offs for development and conservation by explicitly incorporating forest-related culture as a key aspect in development planning.

The research was approached by answering the following questions: What are the forest related cultural features of the people in Vo Nhai districts? How do these features contribute to sustainable development strategies of the area? To answer these research questions, we first describe our methods and proceed as follows: (1) forest-related cultures include local knowledge and adaptive experiences with the natural environment, human health protection, and spiritual and recreational activities; and (2) discussions of potentials of forest-related culture in sustainable development which analyse the contribution of the culture to the environment, economy and societal pillars of sustainable development model. 


\section{Materials and Methods}

\subsection{Research Areas}

The research was conducted in Vu Chan and Nghinh Tuong, two mountain communes of the Southeast Vo Nhai district, Thai Nguyen province, northern Vietnam. It is situated $70 \mathrm{~km}$ of Thai Nguyen city within latitude of 105:58:00E - 106:08:00E and longitude of 21:46:00N - 21:56:30N. Forestland accounts for over 14.5 thousand ha, occupies $23.5 \%$ forestland in Vo Nhai district and $8.1 \%$ forestland in Thai Nguyen province (PFD, 2010). Area of land covered by forests is $88.57 \%$, in which, $86.24 \%$ of natural forests and $2.32 \%$ of plantation forests. This forest area is on limestone of Ngan Son mountain range with many common features of limestone mountain ecosystems in Vietnam. Therefore, fauna and flora diversify with many precious species.

These communes have similar natural and socio-economic conditions and accessibility. The Tay and the Dao, two ethnic minorities in Vietnam, are dominative residents in the area. Their lives are poor and depend on the forest. The number of those categorised as poor households amount to over $50 \%$ of the population. Incomes are generated from agricultural cultivation and forest-related livelihoods. The social services and infrastructure are poorly developed in these areas.

\subsection{Methodology}

This study used qualitative methods including document review, participant observation, indepth interviews, and semi-structured interviews. Together, this approach serves as an effective method to collect in-depth information and insights on the knowledge, culture, and experiences of local conditions relative to the environment (Dey, 1993; Flick, 2009).

- Document review of cultural ecology conceptual framework, cultural forest ecosystem services and indicators, culture aspects of Tay and Dao ethnic people and others related to research about the region provided the researchers a better understanding of the background information and supporting data to process information such as the [re]formulation of questions during interviews and developing an observation guide.

- Data collection were conducted in Vo Nhai district from 2015 to 2019. All in-depth interviews were conducted mainly in 2015 , while semi-structured interviews and participant observation continued between 2015 and 2019.

- In-depth interview with open-ended questions is an effective method for getting interviewees to talk about their personal feelings, opinions and experiences. In-depth interviews allow the researchers to feel flexible to probe initial participant responses by why and how questions (Dey, 1993; Fish et al., 2011; Flick, 2009). We conducted face-to-face interviews with 25 people in 3 participant categories including 15 local people, 4 healers and 6 local government officers. The interview questions were guided by the theme developed, and the interviewee categories were selected to achieve the overall objective of representation for the study. Local people, especially older people and village leaders provided an in-depth understanding of their forest - related culture through their stories and experiences, especially related to local knowledge and participatory forest management. Local healers also provided information of medicinal plant availability and knowledge of medicine collection and treatment. Local government officers also provided additional perspective of the local socio-economic developments and presented their assessments of ecological issues and development. The interviews, lasting 30 to 45 minutes, were recorded and taken note on paper, and later synthesized by the study team.

- Semi-structured interviews were conducted through the observation process and participation with local people. These kinds of interviews depended on the interview contents and situations. Only some questions were pre-determined and new questions arose throughout the interview. Informal conversations with local people in the field provided additional information that researchers about local life and social context. 
- Participant observation in different times during the research period was useful for gaining an understanding of the physical, social, cultural, and economic contexts in which the study participants live; the relationships among and between people, contexts, ideas, norms, and events; and people's behaviours and activities. Data obtained through participant observation also served as a check against participants' subjective reporting of what they believe and do.

The researchers also participated in local cultural activities such as an initiation ceremony of the Dao ethnic group. Illustrative photographs were taken during observation.

Data analysis: The data was transferred from recording into transcripts and noted following information categorization of each issue to be analysed.

\section{Results and Discussion}

\subsection{Forest related culture in the Northern Vietnam}

\subsubsection{Local knowledge of the natural environment}

Residents who live in/near forests regularly forage for food and medicine, hunt, log, etc. Thus, they have gained empirical knowledge of fauna, flora, soil, and other natural environment factors around them. The ethnobotanical knowledge of flora includes aspects such as distribution, morphogenesis, time of growth period, functions, and specificities of each species. The knowledge of fauna focuses on physiology, behaviour, feeding and hunting habits, and interrelation with other species. Some ancient knowledge still exists and is transferred orally until now, while others have disappeared with time.

Concerning flora, local people are experts in timber identification and classification. "Basically, we have to determine the character of leaves, wood grain, bark, wood type" (Interviewee). Local cognition of forest species is also shown in food and medicine findings. They know the use of the whole tree or parts of it (leaves, fruits, flowers, roots, nuts, etc.) and how to use them as a food or medicine. Residents have a firm grasp on growth seasons of trees to extract them, such as when and which ones grow rapidly. "Bamboo shoots that have a bitter taste usually grow in spring (the first and second month of the lunar year) while shoots of "Nứa"1 grow profusely in the summer, shoots of "giang"2grow in autumn".

The knowledge of fauna, such as behaviour and habitats of animals, helps the hunters to be successful. Based on this knowledge, the hunters can set their traps or wait for the time when wild animals go out or go back to their shelters to improve their hunting results.

Knowledge of soil and forestland accumulated in the process of using the land and selecting suitable crops was revealed in site selection for shifting cultivation. They selected areas for slashand-burn cultivation by considering soil colour, abundance of organic matter, or porosity. An eightyyear-old man shared his experience in choosing soil for cultivation stating that "The fine-grained soil is good for upland rice; soil consisting of a mixture of sand and gravel is suitable for maize".

Local knowledge of the natural environment helps people to live and adapt with environmental change. They use forest products for food, medicine, and fuel to survive in the past, and extract aspects of natural ecosystems to improve their living standard during those times. This is especially true about the traditional knowledge that supported people to protect agriculture productivity and product quality in the context of global climate change (ILO, 2019; MoSTE, 2015; Son et al., 2019)

\subsubsection{Adaptation with the natural environment}

Understanding natural environment conditions, local people have experience and skill to adapt with the natural environment in mountainous areas such as their residential siting, sloping land cultivation, healthcare, and other survival skills.

\footnotetext{
${ }^{1}$ Nứa (Vietnamese name of a bamboo species) - Neohouzeauna dullooa (scientific name)

${ }^{2}$ Giang (Vietnamese name of a bamboo species) - Dendrocalamus patellaris (scientific name)
} 
The natural landscape influences resident characteristics of local people. Hamlets or villages (bản), rudimental residential units of the ethnic groups in the northern mountain areas in Vietnam, was named in the ethnic language to correspond with local landscape features like rice fields, valleys, mountains, or mountain passes. Each hamlet has its own territory, defined by a natural boundary, such as mountain ranges, or streams, which are conceded and respected by other hamlets (Khong, 2009). Normally, the hamlets stand against mountains and look over fields or valleys. They usually livein groups of several houses together. Originally, the population distribution was influenced by the natural fragmentation of mountain topography and by characteristics of shifting cultivation in the past. Nowadays, Tay people tend to live nearby the main transport ways while the Dao still live near forests. The scenery of the villages is beautiful and outsiders are often fascinated by its natural beauty. They reflect conditions of standing on high perches, looking down from stilt-houses between the green of forests, paddy fields or corn, interspersed with small roads and cool water streams winding around.

The selection of an area to build a house is mostly based on feng-shui. Ideally, the front of the house should overlook the fields while its back should lean on the mountain. It is also believed that the location for the house facing the confluence of rivers and streams will bring good fortune and a thriving business for the homeowners. They avoid places with high mountains in front of the house, and strange and odd objects that look straight into the house. The stilt houses are a special architecture feature of the Tay and the Dao in Vo Nhai, which has adapted to the natural conditions, weather, and socio-economic conditions in mountain areas. The traditional structure of the stilt houses has the following main features: a house consists of five components, three or one compartment(s) and two lean-tos; a diagonal roof having axe shapes in the corners; wall made of wood or bamboo-wattle; trusses with 3,5,7 stilts. All materials of the traditional house come from the forests with high flora diversity, which indicates that local people used to depend on their natural environment. However, the structure of a stilt house had to suit both the natural environment as well as cultivation purposes. The three-floor structure of stilt houses creates more space for people's activities and for storing agriculture products $(\mathrm{Vu}, 2009)$. Level one, under the floor, stores production tools. Level two (a broader floor) serves as living quarters, cooking and worshiping space. It is an airy and cool space in the summers and dries easily on humid days, which are common weather phenomenon in the north of Vietnam in the Spring. Level three, the boarded attic shelf, stores rice, maize, and other agricultural products. The invention of stilt houses provides safe and strong accommodations that suits high humidity conditions and hot weather, resists wild beasts and fits the cratered terrain ( $\mathrm{Ma}, 2004)$. The structure and function of stilt houses are in harmony with the natural environment creating a beautiful landscape.

Experiences of local people in using sloping land are adaptive ways to live in the mountainous area. They are presented in where/when/how (1) they do swidden cultivation, (2) soil erosion prevention, (3) irrigation system. Shifting cultivation is part of Tay and Dao traditions. They also used to live in surrounding forests. Therefore, they have the tendency to retreat to be nearer the forests and practice shifting cultivation (Mai, 2003). Although shifting cultivation has not been practiced in the area for the last ten years, it is undeniable the master knowledge system of shifting farmers in their environment and sloping land cultivation. Erosion prevention and effective irrigation are major concerns when cultivating on sloping land in tropical mountainous regions. The cultivation methods make less ground surface disturbance and create terraces to reduce the slopes in the highlands. In the irrigation system, people dig trenches from forests or subterranean sheets of water in the forests to the fields. The width and length of trenches depend on the terrain and its topography. When the terrain is inconvenient for digging trenches, they use conduits made from bamboo.

The knowledge to adapt with the natural environment also reveals skills to survive in the forests or to protect from getting lost, safety from wild animal attacks, residential site selection, food finding, and cooking. For example, local people have the necessary skills resulting from their experiences and knowledge of local forests to save them in some urgent situations like losing their 
way, thirst, or anticipation of dangerous animals. "We have to know that forest precisely, if not, we should go follow the way the water flows (...) because water will flow from upper to lower regions" (Interviewee). In gastronomy, the Tay is famous for five-colour steamed sticky rice, also called Đăm đeng steamed sticky rice. Five colours (red, violet, yellow, black and white) are made of different kinds of forest leaves and depend on the materials that have been used.

\subsubsection{Human health protection}

To protect their health, local people have a good knowledge about medicinal plants and various therapeutic methods to treat diseases depending on the disease and the medicinal herbs. For instance, to treat internal organ-related diseases such as renal calculus (kidney stone), heart attack, hepatitis, herbal medicines are used as food or drink. To treat skin diseases, herbs are boiled and decanted to get water for washing, bathing or soaking affected parts. To treat the cuts and the wounds, freshly crushed leaves, some having been chewed or heated before, are applied on the cut or wound for rapid healing. To treat back aches, headaches or aches all over, patients drink medicinal infusions and lie down on a layer of crushed and heated herbs. The medicinal decoctions also differ from plant to plant, disease to disease. Herbs are used fresh or dry. Some are cut into small pieces and sun dried naturally, then processed on fires before being boiled to produce the infusion. Some others are used in a fresh state are boiled or dehydrated on fire before use. The medicine decoction can combine herbs with liquids such as alcohols, water from rice-wash, or clear limewater, as well as with organs of different living species.

In general, the Dao people are famous for medicinal herb use for the treatment of diseases compared to the Tay people. Some of the Dao healers even go to other localities or communities to treat diseases. Women usually play an important role in gathering food and medicine for curing simple ailments such as fever and headaches. Such knowledge is often passed on from mothers to daughters. In addition, certain special persons, such as herbal doctors, have elaborated skills regarding medicinal properties and potencies of certain herbs. They may also be well versed in matters concerning incantations, sorcery and health treatment methods which involve the use of herbs and incantations (Santasombat, 2003). With respect to gender, the Dao women have a greater knowledge about medicinal plants than the men, while in the Tay ethnic group, there are more male healers than females.

\subsubsection{Spiritual and pleasure activities}

Although the Tay and the Dao have different spiritual and religious life, in general, both ethnic minorities also have some similarities in the conception and imagination of the universe and the supernatural world. They believe that the universe has three layers (Heaven or upper layer; Earth or middle layer and Water or under layer) and two worlds (the material world of humans and the intangible world of divinities and ghosts). The intangible world includes Genii and ghosts, including benign ghosts such as ancestor spirits; ghost of the kitchen, soil and wicked ghosts like ghost of the river and streams; spirits of suddenly dead people that can emerge. The benign ghosts sometimes make difficulties for humans. The belief in the intangible world is shown in many aspects of their daily life. Before conducting an important function, people often offer the Genii and ancestors as a way to communicate with them and pray for their support. For example, before moving in a new house, local people always choose an auspicious day and organise the ceremony "phat mộc", which aims to invite the ghost of trees to come back to the forests. After that, an elder man who is considered the embodiment of happiness and virtue brings a "scared flame" to light the kitchen fire. On the day the owner moves into the new house, he must keep the fire burning throughout the night until the next morning, because the Tay believe that as the fire blazes through the night, the family can live in peace and happiness $(\mathrm{Vu}, 2009)$. Some forest products are used to support the spiritual life and rituals such as flowers of wild bananas, an indispensable feature in rituals of the Tay, symbolizing a cock (Khong, 2009). People also use incense, an aroma smoke made from forest 
plants, in divine beings or ancestor rituals. In Vietnamese conceptions, incense burning is a bridge to connect the tangible and intangible world. It is a way to contact to the divine.

The art of the Then folk singing and Tính guitar playing are important features in the Tay's spiritual and cultural life, have have been preserved for many generations. The Then folk singing and Tính guitar playing have become indispensable in the Tay's festivals, The Lunar New Year holidays, and community cultural activities. The materials to make Tính guitar are popular and connect with daily life. The most difficult and important aspect is to choose a gourd which is round, big, and beautiful. The peel should be thick so it has a sharp sound when beaten. An old gourd is hollowed out and soaked in water for ten days. It is then smoothed out and pricked with holes. The front of the guitar is made of Vông timber. In the past, the strings were made of silk cords, today they are made of nylon threads. The long neck of the guitar is made of wood of dâu or thừng mực. It should be light and straight with its length being nine times the length of the player's fist. According to folk experiences, the size of the instrument fits the singing voice of the musician. The Tay use brown tubers, found in forests, as glue to attach the neck of the guitar with the gourd.

Local hunters considered hunting as an activity of pleasure. They feel happy and proud about their hunting success. The hunters keep a part of the prey in the house, for example: a head or horn of dears, teeth or claws of tiger, wild boars, tails of wild boars as a signal of success and pride. It is not difficult to see various hunt trophies hung on stilts or kept in the kitchen area in some local people's homes. Some locals said that they felt excited with the hunt, even if not for food purposes. "At that period, we went to the forests for hunting whenever we wanted or had the call to do so. Sometimes, there was plentiful meat for food, but we still went hunting when someone informed us that there were wild boars or chamois in a specific forest area" (Interviewee). Hunting has been forbidden since the 1990s in favour of wildlife conservation. However, when talking about hunting, some old people felt regret for what they had to give up for a long time. "Sometimes, I miss the days of hunting in the forests. (...) If I had enough strength and hunting was legal, I would like to go for it, but only for food, not for economic purposes" (Interviewee).

Walking in the forest to collect products, hearing the sounds of nature was also expressed as supporting mental health. Most of the interviewees felt relaxed and comfortable when they heard the sounds of birds singing or the lapping of running water. The nature sounds mostly had positive effects on local people's feelings. Local people also felt pleasure when they went to the forest for non-timber product foraging or gathering, or just as a diversion. They held many gatherings for the purposes of getting together whenever they went to the forests, such as for timber and honey. "I will feel sad if I cannot go to the forests anymore. I find some interesting things when I go into forests. For example, when I walk leisurely into the forests, I can find beehives and enjoy the fresh and cool air. This activity is recreation and refreshment" (Interviewee).

\subsection{Potentials of forest-related-culture for sustainable development}

\subsubsection{Natural Conservation}

The local people's knowledge of natural ecosystems and their awareness and attitudes encourage participation and contribution to the success in community-based forest management or participatory forest management (Sirivongs \& Tsuchiya, 2012). Community-based forest management has been adopted as a key national strategy for sustainable forestry and social equity in the Philippines since 1995 which delivered positive environmental impacts such as natural forest conservation and associated biodiversity and watershed protection (Guiang et al., 1999; Lasco \& Pulhin, 2006). Community forestry programs has improved forest conditions, increased forest product abilities, and smallholder livelihoods in Nepal (Gurung et al., 2013). The World Wildlife Fund for Nature (WWF) conduct an assessment in 11 countries (Albania, Bhutan, Brazil, Cameroon, Indonesia, Kenya, Kosovo, Mozambique, Nepal, Papua New Guinea and Peru) in 2010 and reported that community-based forestry has positive impacts on forest ecology, in which forest cover has mostly increased (Beukeboom et al., 2010). FAO summarized that community-based forestry causes 
an increase of the natural capital base of forests such as total area, density, and productive capacity. The summation also noted that in many countries, this overall approach can help to control illegal forest use and thereby improve forest condition (FAO, 2016).

Community-based management has existed for a long time in Vietnam and is recognized in the Law of Forestry Protection and Development since 2004, which was revised into the Forestry Law in 2017. This is an effective way to develop forests and consists of habits and customs of local people who are direct forest users and managers. Local people are the main subjects and are active participants, positive and decisive factors in every local activity, and they clearly understand difficulties and expectations as well as abilities of their communities. For the most effective management of forests, people's participation should be promoted in terms of the correlation between the demand and use, the abundance of resources, and other impact factors (Arnold \& Pérez, 1998; Dương Viết Tình \& Trần Hữu Nghị, 2012; To \& Tran, 2014). It is undeniable the role of local communities in forest management and development. Promoting their knowledge and perception of the forest ecosystem will have positive impacts in forest protection, thereby sustaining forest ecosystem services and human welfare.

Having a good understanding of the natural environment and the benefits to human well-being, local people have proper ways to protect nature and sustain forest ecosystem services. For instance, they prevent soil erosion through their indigenous methods of sloping land cultivation, or sustainable extraction and use of medicinal herbs.

Regarding soil erosion prevention in sloping land, local farmers pock holes and sow seeds, a method that reduces/limits the ground surface disturbance. They create terraces to reduce the slopes in the highlands and transform the terrain to suit their cultivation. The terraced paddy fields are built into steep hillsides or infertile shifting lands that have gentle slopes near the water sources. The terraces function as dams by retaining rainwater, which slowly seeps underground and gently flows on the hillside's surface. Therefore, it prevents landslide and soil erosion. Additionally, the terraces blend in with the overall beauty of the majestic mountainous landscapes and give viewers a great sense of peace and comfort.

Extractive reserves of medicinal plants go along with the use of traditional medicine. Some kinds of medicinal plants were collected and desiccated in growing seasons to store it for necessary cases. A local healer said that he avoided extracting part of plants which can cause the tree to die such as tapping roots, girdling stumps, or destroying the main branches of trees. He said: "For extracting roots of plants, we dug around the tree and cut a half of the lateral roots or rootlets. This method keeps the main root of a tree stable and its function persistent in order to allow the trees to grow after that. For extracting bark and trunk parts, we cut only part of the tree. For extracting leaves, we only pick leaves, and we do not break branches or sprigs, thus, the trees can grow continuously. We seldom use stumps for herbal medicine" (Interviewee).

The point of time to pick the medicinal plants is very important to have the right composition of medicine and preserve plants. They believed that the herbs extracted in the early morning will be the best because the trees have the quintessence or good quality at that time. They do not pick medicinal herbs from 12:00 to 14:00 during the day to avoid heat from the sun that could damage the trees. Some kinds of medicinal herbs have been grown around their houses as ex-situ conservation methods. Forest ecosystem protection and medicinal plant conservation support the preservation of good remedies, which creates livelihood income and healthcare conditions for the local people.

Nguyen's (2018) analyse on the participation of local people in forest management and development at different scales (community, household and personal) was conducted in the same research area. Her research results showed that the local people were conscious and willing to participate in forest management and protection. They also actively participated in forest contracting initiatives and forest plantation programs in the area to green the bare land for forestry economic development. The willingness to participate in forest management and the cooperation 
among the local government and individuals in the community created the strength of forest management and socio-economic development.

\subsubsection{Economic Development}

Natural ecosystems contribute to local economic development through direct or indirect ways. Provisioning goods and products for purposes of domestic use or for selling creates opportunities to obtain cash and noncash income for local households. Wood and non-wood products of the forest ecosystem are used for food, fuel, fodder, healthcare, construction, etc. One case study from the western highlands of Guatemala noted that subsistence income from forests can account for $14 \%$ of household income on average, and $31 \%$ among the poorest households in rural villages (Córdova et al., 2013). Forest ecosystem services contributed to poverty alleviation in mountainous areas in many countries (Fisher et al., 2014; Nkem et al., 2008; Rees \& Population, 2014; Sunderlin et al., 2005; Wunder, 2001). Forestry-related income and livelihoods include contracts for forest protection, forest plantation, medicinal plant growth, or agroforestry, recreation and tourism services. In addition, forests deliver indirect economic benefits from providing safe and secure habitats for people. Forest ecosystems help to diffuse and reduce incidence of pollution, protect against extreme weather patterns, and have positive correlation with reducing disease vectors (Church et al., 2011; Mourato et al., 2010; Perino et al., 2011), providing people a safe environment and good health. The economics benefits of natural ecosystems have been evaluated via direct or proxy indicators by researchers around the world (Farber et al., 2002; Folke et al., 2005; Groot et al., 2010; Pascual et al., 2010).

Table 1: Number of flora species and the utilization of flora in Than Sa - Phuong Hoang natural conservation area

\begin{tabular}{lrrrr}
\hline \multirow{2}{*}{ Phylum } & \multicolumn{5}{c}{ Utilization } \\
\cline { 2 - 5 } & Timber & Medicine & Food & Ornamentation \\
\hline Lycopodiophyta & & 1 & & 2 \\
Polypodiophyta & & 8 & 4 & 6 \\
Gymnospermae & & & 2 & \\
Angiospermae & 319 & 565 & 156 & 76 \\
$\quad$ Dicotyledonae & 311 & 510 & 144 & 55 \\
$\quad$ Monocotyledonae & 8 & 55 & 12 & 21 \\
Total & $\mathbf{3 1 9}$ & $\mathbf{5 7 4}$ & $\mathbf{1 6 2}$ & $\mathbf{8 4}$ \\
\hline
\end{tabular}

Source: (TSPHMB, 2012b)
Table 2: Number of assured vertebrate species in the two research communes

\begin{tabular}{lrrr}
\hline Class & Order & Family & Species \\
\hline Mammalia & 7 & 18 & 29 \\
Eves & 12 & 29 & 50 \\
Reptilian & 2 & 5 & 10 \\
Amphibian & 1 & 2 & 2 \\
Pisces & 4 & 12 & 29 \\
Total & $\mathbf{2 6}$ & $\mathbf{6 6}$ & $\mathbf{1 2 0}$ \\
\hline
\end{tabular}

Source: (TSPHMB, 2012b)

In the research area, the forests have diverse fauna and flora. The flora includes multi-layered canopy, timber species, flowers, including orchids, ferns, and an abundance of liana and caulis species. The area also hosts a number of plants used for multi-purposes such as medicines, food, ornamentation (table 1). The fauna diversity includes mammals, birds, reptilian species, fishes and insects (table 2). The biodiversity of forests in Vo Nhai has the potential to provide goods and services which create livelihood and subsistence income. Moreover, forest conservation is one way to sustain the forest-related culture, landscape beauty which are the foundation of delivering tourism and recreation services, heritage goods (Mourato et al., 2010). Conserving local forest ecosystems could enhance academically and traditionally environmental education which are established but not fully carried out in Vietnam. Thereby, natural forest conservation means maintaining ecosystem services and developing the local economy.

Cultural forest ecosystem services provide new livelihood opportunities for local communities from tourism and recreation, services which have not been developed in the research communes. The economic benefits of ecotourism and nature-based tourism are reported in many cases. The inflow of tourism creates opportunities for establishing businesses such as developing homestays in 
Kampung Pelegong, Malaysia (Kayat, 2010), to facilitate the target market expansion for local weaving products in the Taquile Island of Peru (Asli \& Tasci, 2013), to develop small and medium enterprises (Sebele, 2010) or create secondary sources of income (following agriculture cultivation) for the Bousra people in Cambodia (Kim, Xie, \& Cirella, 2019).

In the connection of natural ecosystem settings in Vo Nhai district and in Thai Nguyen province, tourism could develop and deliver new income-generating opportunities for local people in the two research communes. Special cultural features of the local communities in combination with the natural features and landscape beauty in the chosen areas could provide tourism and recreation activities such as: trekking and walking to discover caves and forests on limestone, nature observation, experiencing local culture, traditional healthcare services, and nature-based education. Local people can participate directly in the tourism sector such as art performance. local tour guides, homestays, etc. They can earn from selling non-wood products and local agricultural products, handy craft productions and medicinal herb growths to serve tourists. Based on indigenous knowledge of the local healers, some medicinal species that are well grown behind the forests or in the local ecological conditions could be developed as commercial products and materials for other areas or in the traditional healthcare services for local tourism. If the traditional healthcare services develop, medicinal species and local knowledge relating to these species will be conserved and concurrently local income will be increased.

\subsubsection{Social cohesion}

Based on benefits of nature conservation and economic development, forest-related cultures indirectly deliver positive impacts on society such as employment, living standard, education improvement for the community. In this part, we focus on social cohesion as an indicator for sustainable development potential of forest-related cultures in the research area. Social cohesion exists when people feel part of a society, family and personal relationships are strong, differences among people are respected, and where people feel safe and supported by others. Social cohesion is relevant to sustainable development because it ensures equity in the benefit distribution and reduces income inequality.

Social cohesion is affected by the surrounding ecosystem and serves as a cultural ecosystem service (MA, 2005) creating representative features of a particular culture. The fragmentation of the terrain has created a residential characteristic based on family groups or hamlets of ethnic communities in the northern mountainous areas of Vietnam to support each other in life and in agricultural production. This mutual relationship has created a cohesion among the community and is expressed through neighbourly relationships in some activities such as collective hunting (in the past), building houses, working together on large events.

Both the Tay and the Dao highly value a good neighbourhood relationship apart from kinship (Khong, 2009). Residing in groups in or near the forests, mountain people need to be solidly united against wildlife attack and help each other in shifting cultivation. They have the same ritual and spiritual life, so they feel the urge to celebrate ritual events together. These are some reasons why they tend to have close coordination in all features of life, from cultivation to spiritual and ritual activities. In daily life, neighbouring relations are expressed in helping each other whenever a family has a big event like a funeral, wedding, building a house, etc. The number of participating guests indicates the quality of the relationship between the host and the neighbours. Building a house is considered a big deal in someone's life that needs the support of others in all steps, from timber logging, timber transportation, building, to celebrating a new house. "I must ask my relatives and neighbours for timber carriage to the villages and to help build the house. Building a new house requires participation of dozens of people" (Interviewee). So, when a new house is built, the host will be invited to meals and rice wine to thank and repay all those that helped. The meals with many people and new house celebrations are social occasions for local people to meet, exchange information and from this, consolidate their neighbour relations. Hunting used to be an activity that 
united people in a community (Tran, 2007). They were coordinated with each other in any action to be successful in the hunt. The party after the hunt and the hunting "booty" division also gave to them joy and camaraderie. In cultivation and production, social relationships are expressed through mutual help in groups of several households. "When sowing seeds, dozens of people were mobilized for help. Someone used a wooden stick to poke holes followed by another to sow the seed. (...) We must exchange labour among families when sowing". (Interviewee). Neighbourhood relations are not only expressed among people in a community, but also among communities or hamlets. Social cohesion creates social stability which is a positive factor and a strength of a society in conflict resolution and solidarity in community development activities.

\section{Conclusions}

A natural living environment is part of the life of mountainous people in Vo Nhai district, Thai Nguyen. The adaptation of their natural environment creates specific cultural features. They have various knowledge of the natural environment, which shape their living and cultivation skills, healthcare, spiritual, and recreational activities. All these features of culture provide various forms of welfare for local people living in/near the forests.

The culture is closely connected with the local forests and can contribute to sustainable development of the locality. Environmentally, local knowledge and living skills enhance natural conservation to maintain social and economic values of the forest. People's perception and awareness of the importance of the forest are significant in achievement's towards communitybased forest management or participation in forest management. Economically, the forest ecosystem provides various goods and services to human well-being, delivering cash and non-cash income to local people. In addition, the economics are based on local culture which are connected closely with forests and landscapes (such as the potential for natural tourism, traditional healthcare services, experiencing local cultures, local agroforestry production) and can create new income opportunities for local people. Socially, the overall cohesion originates from the living environment and cultivation conditions that contribute to a social strength of applying local development strategies.

To integrate forest-related culture in sustainable development, some proposal recommendations for policy makers need to be concerned with the way they plan development strategies and apply them in Vo Nhai districts, Thai Nguyen province, Vietnam. Firstly, the understanding of cultural-environment relationships is key. Local knowledge especially needs to receive adequate attention by scientists and managers. Local knowledge accumulates over generations to protect natural resources and adapt with natural conditions that could support them to cope with changes in the environment, especially in the context of climate change. Secondly, tourism and recreation as part of local development strategies and planning should (a) be based on sustainable conservation and development of local culture, nature ecosystem, and economics; and (b) ensure equity considerations for local communities in comparison with outside stakeholders on the potential for developing new access to livelihoods and employment in the tourism sector. Finally, local communities need supports of scientific knowledge and working skills to create qualified human resources in maintaining the operating systems of tourism and other forest-based economic sectors, because they are the subject of the tourism, who will continue to preserve and develop local tourism attractiveness and support direct forest conservation outcomes.

\section{Author Contribution}

Thi Tan Huong Ngo and Thi Phuong Mai Nguyen conceived and designed the fieldwork and drafted the manuscript; Thi Phuong Mai Nguyen and Thi Huong Duong, Thi Hue Ly collected and analysed data; Thi Tan Huong Ngo and Thi Huong Duong contributed materials and documents; Thi Phuong Mai Nguyen wrote the paper. 


\section{Acknowledgments}

Sincere thanks are due to the anonymous reviewers for their valuable comments on earlier drafts of this paper. Special thanks to the numerous local people involved in Vu Chan and Nghinh Tuong communes, Thai Nguyen provinces, in particular for their cooperation and willingness to share information. Great thanks to Thai Nguyen University under funding for the project series ĐH2018-TN08-02 and ĐH2019-TN06-01.

\section{Conflicts of Interest}

I affirm that the authors have no conflict of interest in producing this article. I affirm that the founding sponsors had no role in the design of the study, in the collection, analysis, or interpretation of data; in the writing of the manuscript, and in the decision to publish the results.

\section{References}

Arnold, J. E. M., \& Pérez, M. R. (1998). The role of non-timber forest products in conversation and development. In E. Wollenberg \& A. Ingles (Eds.), Income from the forests - Methods for the development and conservation of forest products for local communities (pp. 17-41). CIFOR.

Asli D.A. Tasci, K. J. S. and S. S. Y. (2013). COMMUNITY BASED TOURISM Finding the Equilibrium in the COMCEC Context - Setting the Pathway for the Future. In Comcec Cooordination Office. Retrieved from http://www.mod.gov.tr/Lists/RecentPublications/Attachments/4/COMMUNITY BASED TOURISM Finding the Equilibrium in the COMCEC Context.pdf

Bennett, J. W. (1944). The interaction of culture and environment in the smaller societies. American Anthropologist, 46(4), 461-478. https://doi.org/10.1525/aa.1944.46.4.02a00040

Beukeboom, H. J. ., Van der Laan, C., Van Kreveld, A., \& Akwah, G. (2010). Can community forestry contribute to livelihood improvement and biodiversity? Netherlands.

Bieling, C., \& Plieninger, T. (2013). Recording Manifestations of Cultural Ecosystem Services in the Landscape. Landscape Research, 38(5), 649-667. https://doi.org/10.1080/01426397.2012.691469

Brancalion, P. H. S., Cardozo, I. V., Camatta, A., Aronson, J., \& Rodrigues, R. R. (2014). Cultural ecosystem services and popular perceptions of the benefits of an ecological restoration project in the Brazilian Atlantic Forest. Restoration Ecology, 22(1), 65-71. https://doi.org/10.1111/rec.12025

Burkhard, B., Kandziora, M., Hou, Y., \& Müller, F. (2014). Ecosystem service potentials, flows and demands - Concepts for spatial localisation, indication and quantification. Landscape Online, 34(1), 1-32. https://doi.org/10.3097/LO.201434

Chan, K. M. A., Satterfield, T., \& Goldstein, J. (2012). Rethinking ecosystem services to better address and navigate cultural values. Ecological Economics, 74(0), 8-18. https://doi.org/http://dx.doi.org/10.1016/j.ecolecon.2011.11.011

Church, A., Burgess, J., Ravenscroft, N., Bird, W., Blackstock, K., Brady, E., ... Winter, M. (2011). Cultural Services. The UK National Ecosystem Assessment Technical Report. UK National Ecosystem Assessment., 633-692.

Costanza, R., Arge, R., Groot, R. De, Farberk, S., Grasso, M., Hannon, B., ... Suttonkk, P. (1997). The value of the world' s ecosystem services and natural capital. Nature, 387(May), 253-260. https://doi.org/10.1038/387253a0

CRES. (2001). Mountain areas in Northern Vietnam, some issues of environments and socioeconomy. National Political Publishing House.

Daily, G. C. (edt). (1997). Nature's services: Societal dependence on natural ecosystems. Retrieved from http://willsull.net/la370/resources/Module-2/Daily.pdf

Daniel, T. C., Muhar, a., Aznar, O., Boyd, J. W., Chan, K. M. a., Costanza, R., ... Spierenburg, M. (2012). Reply to Kirchhoff: Cultural values and ecosystem services. Proceedings of the National Academy of Sciences, 109(46), 3147. https://doi.org/10.1073/pnas.1213520109 
Dey, I. (1993). Qualitative Data Analysis. In Routledge. https://doi.org/10.1136/ebnurs.2011.100352

Do, H. C. (2012). Khảo sát sử dụng tài nguyên cơ sở tại thôn ưu tiên thuộc khu bảo tồn Thần SaPhượng Hoàng (Survey results of base resource utility in priority villages in Than Sa-Phuong Hoang Natural Reserve Areas).

Dương Viết Tình, \& Trần Hữu Nghị. (2012). Lâm nghiệp Cộng Đồng ở Miền Trung Việt Nam. Nhà xuất bản Nông nghiệp Hà Nội.

FAO. (2009). Where is the future for cultures and forests? Indigenous Peoples and Forest Management in 2020. Bangkok: FAO regional office for Asia and the Pacific.

FAO. (2016). Forty years of community-based forestry - review of its extent and effectiveness (No. 16). Rome.

Farber, S. C., Costanza, R., \& Wilson, M. A. (2002). Economic and ecological concepts for valuing ecosystem services. Ecological Economics, 41(The Dynamics and Value of Ecosystem Services: Intergrating Economic and Ecological Prespective), 375-392.

Fish, R., Burgess, J., Chilvers, J., Footitt, A., Haines-Young, R., Russel, D., \& Winter, M. (2011). Participatory and Deliberative Techniques to Embed an Ecosystems Approach into Decision Making: An Introductory Guide. Retrieved from

http://scholar.google.com/scholar?hl=en\&btnG=Search\&q=intitle:Participatory+and+deliber ative+techniques+to+embed+an+ecosystems+approach+into+decision+making+:+An+introdu ctory+guide\#3

Fisher, J. A., Patenaude, G., Giri, K., Lewis, K., Meir, P., Pinho, P., ... Williams, M. (2014). Understanding the relationships between ecosystem services and poverty alleviation: A conceptual framework. Ecosystem Services, 7, 34-45. https://doi.org/10.1016/j.ecoser.2013.08.002

Flick, U. (2009). An Introduction to Qualitative Research- Fourth edition sage. London, England: SAGE Publications Ltd.

Folke, C., Fabricius, C., Cundill, G., \& Schulze, L. (2005). Communities, Ecosystems, and Livelihoods. Sub-Global Assessments of the Millennium Ecosystem Assessment, 261-277. https://doi.org/10.1080/00220389908422619

GIZ. (2018). Integrating Ecosystem Services Into Development Planning- A stepwise approach for practitioners. Retrieved from http://books.google.pt/books?id=at3soQEACAAJ\&amp;dq=intitle:Integrating+Ecosystem+Ser vices+into+Development+Planning+A+stepwise+approach+for+practitioners+based+on+the+ TEEB+approach\&amp; $h \mathrm{~h}=\& a m p ; c d=1 \& a m p ;$ source=gbs_api

Goucher, C., LeGuin, C., \& Walton, L. (1998). Changing Environments, Changing Societies. In In the Balance: Themes in World History. Boston: McGraw-Hill.

Groot, R. De, Fisher, B., Christie, M., Aronson, J., Braat, L., Gowdy, J., ... Shmelev, S. (2010). Integrating the ecological and economic dimensions in biodiversity and ecosystem service valuation.

Guiang, E. S., Borlagdan, S. B., \& Pulhin, J. M. (1999). Community-based forest management in the Philippines (Vol. 97). https://doi.org/10.1093/jof/97.11.26

Gurung, A., Bista, R., Karki, R., Shrestha, S., Uprety, D., \& Oh, S. E. (2013). Community-based forest management and its role in improving forest conditions in Nepal. Small-Scale Forestry, 12, 377-388. https://doi.org/10.1007/s11842-012-9217-z

ILO. (2019). Indigenous peoples and climate change: Emerging research on traditional knowledge and livelihoods. Retrieved from https://www.ilo.org/wcmsp5/groups/public/---ed_protect/--protrav/---ilo_aids/documents/publication/wcms_686780.pdf

Kayat, K. (2010). The Nature of Cultural Contribution of a Community-based Homestay Programme. Munich Personal RePEc Archive, (25320), 145-159.

Khong, D. (Eds). (2009). Section 4: Inhabitants and Ethnicities. In The Gazetteer of Thai Nguyen 
Province (p. 255). Vietnam National Political Publish House.

Kim, M., Xie, Y., \& Cirella, G. T. (2019). Sustainable transformative economy: Community-based ecotourism. Sustainability (Switzerland), 11(18), 1-15. https://doi.org/10.3390/su11184977

Lasco, R. D., \& Pulhin, J. M. (2006). Environmental impacts of community-based forest management in the Philippines. International Journal of Environment and Sustainable Development, 5(1), 46-56. https://doi.org/10.1504/IJESD.2006.008682

Le, T. C. (1998). Mối quan hệ giữa kiến thức bản địa, văn hóa và môi trường ở vùng núi Việt Nam (Relationships between indigenous knowledge, culture and environment in moutain regions in Vietnam). In Kiến thức bản địa của đồng bào vùng cao trong nông nghiệp và quản lý tài nguyên thiên nhiên (Indigenous knowledge of highland people in agriculture and natural resource management) (pp. 211-220). Ha Noi, Vietnam: Hanoi Agriculture Publishing House.

Le, T. C. (1999). Vietnam: traditional cultural concepts of relations with the natural environment. Asian Geographer, 18(1-2), 67-74. https://doi.org/10.1080/10225706.1999.9684048

MA. (2003). Ecosystems and Human Well-being: A framework for assessment. Island Press, Washington, DC.

MA. (2005a). Ecosystem and Human well-being: Multiscale Assessment. Island Press, Washington, DC.

MA. (2005b). Ecosystem and Human Well-being (vol 1) Current state and trends. Island Press, Washington, DC.

MA. (2005c). Ecosystem Services and Human Well-being: Policy Responses. Island Press, Washington, DC.

Ma, N. D. (2004). Nhà sàn truyền thống của người Tày ở đông bắc Việt Nam (Traditional stilt house of the Tay in Northesten Vietnam). Hanoi Social Science Publishing House.

Mai, V. T. (2003). Promotion of agroforestry in swiddencultivation area: a case study of Tay Community in Northwest Vietnam. Hanoi Agricultural University, Hanoi, Vietnam.

Milcu, A. I., Hanspach, J., Abson, D., \& Fischer, J. (2013). Cultural Ecosystem Services : A Literature Review and Prospects for Future Research. Ecology And Society, 18 (3)(44).

MOSTE. (2015). Indigenous and Local Knowledge and Practices for Climate Resilience in Nepal. Mainstreaming Climate Change Risk Management in Development, Ministry of Science, Technology and Environment (MoSTE), Kathmandu, Nepal.

Mourato, S., Atkinson, G., Collins, M., Gibbons, S., Mackerron, G., \& Resende, G. (2010). Economic Analysis of Cultural Services.

Nguyen, T. P. M. (2018). The role of the local people in forest management and development in Vo Nhai district, Thai Nguyen province. Socio-Economic and Environmental Issues in Development, 815-824. Vietnam: Labour-Social Publishing House.

Nguyen, T. T. (2014). Nghiên cứu đa dạng sinh học và đề xuất một số giải phát bảo tồn cây gỗ trên núi đá vôi ở khu bảo tồn thiên nhiên Thần Sa - Phượng Hoàng, tỉnh Thái Nguyên (Research on the diversity and proposed solutions for woody plant species conservation on limestone $i$. Thai Nguyen University of Agriculture and Forestry.

Nkem, J., Idinoba, M., Santoso, H., Perez, C. J., Forner, C., Locatelli, B., \& Kanninen, M. (2008). Prioritisation for Adaptation in Tropical Forest Ecosystems. In CIFOR Working Paper (Vol. 44). Retrieved from http://www.cifor.cgiar.org/Knowledge/Publications/Detail?pid=2762

Norton, L. R., Inwood, H., Crowe, a., \& Baker, a. (2012). Trialling a method to quantify the "cultural services" of the English landscape using Countryside Survey data. Land Use Policy, 29(2), 449-455. https://doi.org/10.1016/j.landusepol.2011.09.002

Pascual, U., Muradian, R., Brander, L., Gómez-baggethun, E., Martín-lópez, B., Verma, M., ... Turner, R. K. (2010). Chapter 5 The economics of valuing ecosystem services and biodiversity. The Economics of Ecosystems and Biodiversity. Ecological and Economic Foundations, (March), 183-255. https://doi.org/10.4324/9781849775489

Perino, G., Andrews, B., Kontoleon, A., \& Bateman, I. (2011). UK NEA Economic Analysis Report: 
Economic Assessment of Ecosystem Services provided by UK Urban Habitats. Social Research, (May), 1-58.

PFD. (2010). Planning forest protection and development in Thai Nguyen province in period 2011 2020. Thai Nguyen province.

Phan, T. A. D., \& Le, T. C. (2017). Sinh thái nhân văn và phát triển bền vững: Nghiên cứu ở Việt Nam (Human Ecology and Sustainable Development: research in Vietnam). Human Ecology and Sustainable Development: Some Issues from Theory to Practice, 3-22. Ha Noi, Vietnam: Agricultural Publishing House. Hanoi.

Plieninger, T., Dijks, S., Oteros-Rozas, E., \& Bieling, C. (2013). Assessing, mapping, and quantifying cultural ecosystem services at community level. Land Use Policy, 33(July 2015), 118-129. https://doi.org/10.1016/j.landusepol.2012.12.013

Prado Córdova, J. P., Wunder, S., Smith-Hall, C., \& Börner, J. (2013). Rural income and forest reliance in highland guatemala. Environmental Management, 51(5), 1034-1043. https://doi.org/10.1007/s00267-013-0028-6

Rees, W. E., \& Population, S. (2014). An Ecological Economics Perspective on Sustainability and Prospects for Ending Poverty An Ecological Economics Perspective on Sustainability and Prospects for Ending Poverty. 24(1), 15-46.

Retallack, M., \& Schott, S. (2014). Cultural values and ecosystem management at the subwatershed level. Environmental Policy and Governance, 363(July), 351-363. https://doi.org/10.1002/eet.1652

Santasombat, Y. (2003). Biodiversity local knowledge and sustainable development. Regional Center for Social Science and sustainable Development (RCSD), Faculty of Social Sciences, Chiang Mai University.

Satz, D., Gould, R. K., Chan, K. M. a, Guerry, A., Norton, B., Satterfield, T., ... Klain, S. (2013). The challenges of incorporating cultural ecosystem services into environmental assessment. Ambio, 42(6), 675-684. https://doi.org/10.1007/s13280-013-0386-6

Schaich, H., Bieling, C., \& Plieniger, T. (2010). Linking ecosystems services with cultural landscape research. Gaia, 19(4), 269-277.

Sebele, L. S. (2010). Community-based tourism ventures, benefits and challenges: Khama Rhino Sanctuary Trust, Central District, Botswana. Tourism Management, 31(1), 136-146. https://doi.org/10.1016/j.tourman.2009.01.005

Sirivongs, K., \& Tsuchiya, T. (2012). Relationship between local residents' perceptions, attitudes and participation towards national protected areas: A case study of Phou Khao Khouay National Protected Area, central Lao PDR. Forest Policy and Economics, 21, 92-100. https://doi.org/10.1016/j.forpol.2012.04.003

Son, H. N., Chi, D. T. L., \& Kingsbury, A. (2019). Indigenous knowledge and climate change adaptation of ethnic minorities in the mountainous regions of Vietnam: A case study of the Yao people in Bac Kan Province. Agricultural Systems, Elsevier, 176 (C). https://doi.org/10.1016/j.agsy.2019.102683

Sunderlin, W. D., Belcher, B., Santoso, L., Angelsen, A., Burgers, P., Nasi, R., \& Wunder, S. (2005). Livelihoods, forests, and conservation in developing countries: An overview. World Development, 33(9 SPEC. ISS.), 1383-1402. https://doi.org/10.1016/j.worlddev.2004.10.004

Szücs, L., Anders, U., \& Bürger-Arndt, R. (2015). Assessment and illustration of cultural ecosystem services at the local scale - A retrospective trend analysis. Ecological Indicators, 50, 120-134. https://doi.org/10.1016/j.ecolind.2014.09.015

TEEB. (2010). The Economics of Ecosystem and Biodiversity for local and regional policy makers. In Report. Retrieved from http://www.teebweb.org/wp-content/uploads/Study and Reports/Reports/Local and Regional Policy Makers/D2 Report/TEEB_Local_PolicyMakers_Report.pdf

To, X. P., \& Tran, H. N. (2014). Giao đất giao rừng trong bối cảnh tái cơ cấu ngành lâm nghiệp: Cơ 
hội phát triển rừng và cải thiện sinh kế vùng cao. Hue, Vientam.

Tran, H. H. (2007). Tri thức bản địa trong săn bắn của người Dao ở Sa Pa, tỉnh Lào Cai (Local knowledge in hunting of The Dao in Sapa, Lao Cai province). In Ethnography Report of the year 2006. Social Sciences Publishing House.

TSPHMB. (2012a). Báo cáo đánh giá nhanh đa dạng sinh học tại khu bảo tồn thiên nhiên Thần Sa Phượng Hoàng, huyện Võ Nhai, tỉnh Thái Nguyên (Rapid appreciation of biodiversity in Than Sa-Phuong Hoang natural conservation area, Vo Nhai district, Thai Nguyen province).

TSPHMB. (2012b). Thuyết minh dự án đầu tư bảo vệ và phát triển rừng khu bảo tồn Thần Sa Phượng Hoàng, giai đoạn 2011-2020 (Project of Investment of protection and development for Than Sa - Phuong Hoang Nature Conservation Area: Period 2011 - 2020). Vo Nhai, Thai Nguyen.

Vu, Q. K. (edt). (2009). The Tay in Vietnam. VNA publishing house.

Wunder, S. (2001). Poverty alleviation and tropical forests-what scope for synergies? World Development, 29(11), 1817-1833. https://doi.org/10.1016/S0305-750X(01)00070-5 